\title{
Iść, czyli jechać. Językowy obraz świata w cyklolekcie
}

\section{Iść (walk), that is jechać (ride). Linguistic image of the world in Polish cycling sociolect}

\author{
Stefan Wiertlewski \\ SZKOŁA JĘZYKOWA, UNIWERSYTET IM. ADAMA MICKIEWICZA \\ 28 CZERWCA 1956 R. NR 198, 61-485 POZNAŃ \\ wiertleamu.edu.pl
}

\begin{abstract}
Reconstructing the specific linguistic image of the world embedded in the social varieties of language is one of the major concerns of sociolinguistics. This paper shows that in Polish cycling sociolect two common verbs iść (walk) and chodzić (walk) are used with the meaning of jechać (ride). A huge number of word complexes and phraseological units with these verb analysed by the author justify the opinion reflected in the conceptual metaphor that RIDING A BIKE IS WALKING.
\end{abstract}

\section{Wstęp}

W przyjętej w niniejszym tekście perspektywie socjolingwistycznej, cyklolekt, czyli

język używany przez kolarzy, a raczej przez szeroko pojęte grono ludzi w rozmaity sposób związanych z rowerami i jazdą na rowerze, stanowi (obok np. gwar młodzieżowych, slangów studenckich, żargonów przestępczych oraz języków subkultur, grup hobbystycznych i poszczególnych profesji) jedną z licznych środowiskowych odmian polszczyzny zwanych socjolektami. Granice między nimi, zwłaszcza dla laików, nie są ostre, tym bardziej, że zachodzi między nimi nieustająca interakcja, polegająca choćby na wzajemnym przenikaniu się i zapożyczaniu leksyki. Dodam, że to właśnie leksyka decyduje o specyfice danej odmiany językowej, gdyż jej składnia jest w zasadzie identyczna z zasadami gramatycznymi obowiązującymi w odmianie ogólnej języka polskiego. Podobnie jest w cyklolekcie, gdzie występujące 


\section{Investigationes Linguisticae, vol. XLII}

różnice, np. w zmianie wzorca fleksyjnego (np. dojechać kogoś, dokręcić pająk, odejść komuś, przejść kogoś, wygrać klasyk, zrobić stoła, koszul, pedała, widet) są stosunkowo nieliczne i można je pominąć, koncentrując się właśnie na leksyce. Ta z kolei obejmuje jednostki ciągłe, czyli leksemy (np. cykloza, główka, gravel, grillować, paczmej, podsiodłówka, rant, szytka, wachlarz, zajechany, zmarszczka) oraz nieciągłe, czyli połączenia wyrazowe o rozmaitej naturze (np. czesać triki, jazda on sight, klątwa tęczowej koszulki, sunąć słoniem, wystawić koło, ubita noga, zrobić rybkę), w tym także powiedzonka (np. Dzisiaj zdychasz, jutro kosisz., Kolarz, jak wiadomo, nie hamuje., Najgorszy wyścig jest najlepszym treningiem., Przyjemność to największy wróg kolarza., Waty watami, baza się liczy., Żeby jeździć, trzeba jeździć.).

Analiza odpowiednio obszernego zbioru leksyki (także środowiskowej) pozwala rozpoznać specyficzny obraz rzeczywistości zapośredniczonej poprzez język i wyobrażeń przezeń przywoływanych, gdyż to właśnie za pomocą języka mówimy o rzeczywistości i w dużej mierze przez język właśnie ją poznajemy - tego dotyczy termin zapośredniczenie. Zarazem jest to też rzeczywistość przez język współkreowana i głównie poprzez język dostępna. Dotyczy to również cyklolektu, podobnie jak wszelakich innych socjalnych odmian języka. Dodam, że obraz ów jest przekazywany kolejnym uczestnikom rozważanego środowiska wraz z nabywaniem przez nich znajomości interesującego nas tutaj socjolektu. Ponadto, język pełni przy tym funkcję grupotwórczą, gdyż „...grupa tworzy język, a język tworzy grupę społeczną.” (Grabias 1997:13). Badanie socjalnych odmian języka w związku z tym powinno również obejmować rekonstruowanie obecnego w nich językowego obrazu świata, przez który rozumie się „zawartą w języku, różnie zwerbalizowaną interpretację rzeczywistości dającą się ująć w postaci sądów o świecie” (Bartmiński 2006: 12). Ponieważ „Określony sposób odbierania przez człowieka otaczającej rzeczywistości odzwierciedla się w języku” (Handke 2008: 41), dlatego zgadzam się, że „Najważniejszym narzędziem analizy lingwistycznej jest językowy obraz świata” (Piekot 2008: 42), a dokładniej jego rekonstruowanie. Wybór takiego podejścia pozwala też spełnić postulat zgłoszony np. przez Grabiasa (1997: 83), aby w badaniach socjolingwistycznych wyjść poza „etap gromadzenia materiału leksykalnego". 
Stefan Wiertlewski: Iść, czyli jechać. Językowy obraz świata w cyklolekcie

Poniżej przedstawię jeden z językowych obrazów jazdy na rowerze ewokowany przez wyrażające zmianę lokalizacji w przestrzeni wspólnoodmianowe czasowniki iść - chodzić (o innych językowych obrazach tejże rekonstruowanych $\mathrm{z}$ wykorzystaniem koncepcji metafory pojęciowej, a także o zakresie rozważanego socjolektu i źródłach przywołanego materiału językowego pisałem m.in. w: Wiertlewski 2016).

\section{Czy jazda na rowerze to chodzenie?}

Jak pokazuje nawet pobieżna analiza zgromadzonego przeze mnie materiału językowego, o jeździe na rowerze można również mówić za pomocą czasowników ruchu chodzić i iść (wraz z derywatami), przy czym przypadki ich użycia są bardzo liczne. Zacznę od kolokacji iść mocno, używanej w znaczeniu 'jechać z całych sił' (Miałem ambitny plan iść mocno podjazd, jednak nie starczyło mi sił.). Czasami zresztą wystarczy użycie samego czasownika iść (Niesamowicie Bodi poszedt. Pod górę poszedt jak nigdy., Atak Włochów poszedt już na podjeździe., Sagan czując nacisk poszedł $w$ prawo, by samemu nie wylecieć.). Z kolei, iść mocno $w$ korbach znaczy "pedałować na stojąco" (Było tak stromo, że część peletonu szła $w$ korbach). Ich często przywoływanymi synonimami są iść petna para (Na finiszu będa iść petna para, żeby rozprowadzić lidera), iść ostro (Tak ostro szli po tych wąskich szosach.), iść na maksa (Nibali poszedt na maksa na podjeździe.), iść na 10o\% (Na zjeździe Hiszpan i Thomas De Gendt nie poszli na 100 procent.), idzie atak (Na takim podjeździe atak idzie z prędkością ok. 25km/h.), idzie gaz (Na każdym górskim etapie idzie gaz), idzie ogień (Rzadko się zdarza, że idzie ogień od samego dołu aż po szczyt.), idzie ostre tempo (Trasa jest dość płaska, więc od startu idzie ostre tempo.), idzie palnik (To drugi podjazd podczas tego Giro, kiedy poszedt palnik pod górę.), idzie petarda (Jeśli będzie boczny wiatr, to $w$ peletonie pójdzie taka petarda, żeby pourywać kogo się da.), idzie robota (W mocnym zespole także na podjazdach idzie robota.), idzie rura (Dzisiaj rura idzie od startu.), idzie tempo (27km i ucieczki jeszcze nie ma. Co tam za tempo idzie?). Dzieje się tak, gdy zawodnik jest w dobrej formie, czyli gdy noga idzie swoje. Kolejne wyrażenia, takie jak iść wszystko (Jeśli chce zachować żótta koszulkę, musi dzisiaj išć wszystko.) i iść w trupa (Jutro całe Sky powinno iść w 
trupa przez ostatnie parę kilometrów.) odnoszą się do sytuacji, gdy wysiłek kolarzy wkładany w jazdę zdaje się być ponad ludzkie siły.

Podobne znaczenie do powyżej przywołanych mają liczne porównania, używane zresztą nie tylko w cyklolekcie, takie jak np. iść jak burza (Po Paryż - Nicea byłem przekonany, że Kwiato będzie iść jak burza.), iść jak dzik (Herrada poszedt jak dzik.), iść jak ekspres (Na finiszu poszedt jak ekspres.), iść jak maszyna (Contador poszedl jak maszyna.), iść jak motor (Cavedish nie zawsze chodzit jak motor.), iść jak pocisk (Poszedt jak pocisk.) iść jak rakieta (Zdenek poszedt do przodu jak rakieta.), iść jak strzała (Na dzisiejszym etapie idzie jak strzała.), iść jak torpeda (Przed zakrętem musi pójść jak torpeda.) iść jak wściekty (Żeby wygrać, $w$ końcówce musi iść jak wściekły.), iść jak wicher (Nie wystarczy iść jak wicher. Ważna jest też strategia.). Kolejny przykład, Kobiece wyścigi zawsze były bardzo szybkie. Najszybsze chyba w Holandii, gdzie od startu szło 5okm/h., mówi po prostu o tym, że peleton jechał w danym momencie bardzo szybko ze wspomnianą prędkością.

Natomiast pytanie Czy oni wiedza, jak ciągnąć, kiedy idzie? dotyczy kwestii, jak jechać i z jaką prędkością, kiedy zaczęły się ucieczki, co można także wyrazić za pomocą konstrukcji idzie gaz i wyciągarka lub idzie gaz i wyciągara (Od połowy etapu szedt taki gaz i wyciaggara, że ciężko było nawet coś zjeść.). Najczęściej oznacza to, że idzie zaciąg (Na wzniesieniu poszedł zaciąg.) i jednocześnie idzie selekcja (Wtedy poszedl gaz i selekcja.). Podobne znaczenie ma fraza iść na petnym gazie (Chcę po prostu iść na petnym gazie, gdy będzie trzeba.). Jeśli jednak sił ubywa, ale mimo tego kolarz nie rezygnuje i wkłada maksymalny wysiłek w jazdę, można wówczas powiedzieć, że idzie na zapieku (Gilbert potrafi pójść na zapieku.) lub idzie na oparach (Dzisiaj cała czołówka sprawiała wrażenie, że szła na oparach.). Najlepsi potrafią na podjazdach iść z dużej płyty, iść z dużej tarczy (14km o nachyleniu 3\% idzie się z dużej tarczy.), czyli iść z ciężkiego obrotu (Na tym podjeździe nie można iść z ciężkiego obrotu, bo się koło zacznie ślizgać.), albo iść na grubo (Póki co, Fabian idzie na grubo.). Natomiast wyrazem uznania tego, że kolarz jest mocny jest stwierdzenie, że idzie jak przecinak (Nawet jak mam kryzys na 50 kilometrze, to potem znowu ide jak przecinak.). Najlepsi, gdy są w formie, to potrafia dtugo iść te $360-400$ watt, 
Stefan Wiertlewski: Iść, czyli jechać. Językowy obraz świata w cyklolekcie

czyli generować właśnie taką ogromną moc. Ponieważ nie wszyscy wytrzymują wyścigi wieloetapowe, niektórzy powinni raczej iść klasyki, czyli starować w wyścigach jednodniowych (Moim zdaniem, Michat powinien chodzić klasyki kosztem etapów.).

Podczas jazdy w grupie, czyli gdy idą $w$ grupie, kolarze są bardzo czujni, gdyż oczekują, że ktoś będzie próbował uciekać, czyli iść w odjazd (Dla mnie, nie ma co ryzykować, tylko iść $w$ odjazd. $Z$ niego też można wygrać etap.), lub iść $w$ ucieczkę. Można też powiedzieć prościej, że z peletonu idzie odjazd, ida ucieczki (Idą kolejne ucieczki. Sylwester jedzie wysoko w peletonie.) lub poszła ucieczka po mocnej akcji, lub od startu ida ataki (Kiedy Szmyd ciagnie, to potem zazwyczaj ida ataki.), ida skoki (Zawodowcy się szanują. To w amatorce bez przerwy ida skoki.) i idzie przyspieszenie (Grupa lidera się obudziła i od razu idzie przyspieszenie.), czyli poszło ostro (Od startu poszło tak ostro, że najlepsi się pogubili.). Kolarze czasami uzgadniają zorganizowanie ucieczki i wtedy wystarczy zapytać Idziesz?

Reakcja peletonu na ucieczkę oznacza, że idzie kontra, czyli ktoś idzie za grupa (Polan poszedt za pierwsza grupq - kasuje, czy idzie na przekaźnik?) i próbuje dojść ucieczkę, co może skończyć się tym, że peleton idzie w strzępy, zwłaszcza, gdy idzie rzeźnia. Gdy komuś zależy na dobrej lokacie, a zwłaszcza, gdy idzie w wyścigu jako lider grupy, to należy iść z ucieczkami, iść za ucieczka (Paterski poszedt za ucieczka.), iść $w$ ucieczkę (Uważam, że Rafał nie powinien iść $w$ ucieczkę, nawet jak Rodrigez $w$ niej będzie.), zwłaszcza, gdy idzie się po etap (Lotto dzisiaj idzie po etap), idzie na etap (Szkoda, że Visconti wygrat, mogłem iść na etap.), idzie po punkty na lotnej, idzie na rekord, idzie po rekord (Chciat iść na rekord w jeździe godzinnej.) lub idzie się na generalkę (Jeśli chce iść na generalkę, to musi więcej pracować w górach.). Można też iść po górska premię (Rubiano idzie po górska premię.), iść po złoto (Holender idzie po złoto.), iść po koszulkę (Sagan idzie po zielona koszulkę., Atapuma idzie po grochy na TdF., Martin idzie po punktowa., Owsian idzie po koszulę.), iść po akcję (Roelands idzie po akcję roku.), iść na dublet (Alberto idzie na dublet Giro - Tour.), iść po miejsce (Szmyd idzie po 7 miejsce.) i iść po zwycięstwo (Bodi poszedt po 
zwycięstwo w czasówce.). Należy wtedy po prostu iść na maksa (Evans szed na maksa przed samą meta.), co znaczy czasami, że nie wystarczy wyłącznie iść z nogi (Każdy idzie na finiszu jak chce, ale mi się wydaje, że powinien bardziej bujać ten rower, a nie tylko z nogi iść.).

Większość z ataków kończy się jednak niepowodzeniem, nawet, gdy poszło bardzo mocno (Na rundach poszto mocno.), gdy idzie dobre tempo (Żadnej ucieczki peleton nie puszcza. Cały czas idzie dobre tempo.) i udało się komuś np. odejść na kilka minut (Dziś peleton nie pozwolit ucieczce odejść na więcej niż 3 minuty.), gdyż, gdy idzie pościg peleton często dochodzi ucieczkę, czyli dochodzi grupę (Jeśli Majce nic się nie stało, to powinien dojść grupę Froome’a na tym podjeździe.) i wówczas do mety przyjeżdża większa liczba kolarzy, czyli wszystko się schodzi (Wszystko się zeszło. Do mety już niedaleko.) lub grupy się zeszły (Po zjeździe grupki się zeszły.), a dotychczasowi uciekinierzy wchodza w kota, czyli jadą w środku lub z tyłu peletonu odpoczywając. Dzieje się tak zwłaszcza, gdy na czoło stawki wychodzi zespół zainteresowany zlikwidowaniem ucieczki (Sabatini musiał wcześnie wyjść na czoło stawki, żeby zamknać lukę.), lub na czoło peletonu wychodza ekipy sprinterów (To płaski etap, więc na czoło wychodza grupy sprinterów rozprowadzając swoich liderów.). Wówczas idzie wysokie tempo (Od poczatku poszło wysokie tempo i zaczęła się selekcja.), wszyscy ida na fulla, czyli kolarze ida petna szybkościa, albo ida petnym sprintem, czyli idzie gaz (Na Gliczarowie idzie absolutny gaz.). Czasami jednak zawodnicy schodza się dopiero na rundach kończących wyścig w danej miejscowości i wówczas peleton idzie ława (Na szczęście jest szeroko, więc moga iść ława.), a zawodnicy najmocniejszej ekipy jadą jeden za drugim tworząc formację, o której się mówi, że idzie pociagg ( $\mathrm{Na} \mathrm{TdF}$ tu by poszedt taki pociag, że nawet Moreno nie wyskoczyłby 7oo metrów przed meta.).

Najlepszy kolarz może przejść do przodu peletonu (Dziwna ta strata Aru. Nie miat siły przejść do przodu na płaskim?), iść do przodu (Na $1 \mathrm{~km}$ przed meta jest odruch siadania na kole każdemu, kto idzie do przodu.) i iść na zwycięstwo (Który z tej dwójki ma szanse iść w końcówce na zwycięstwo?), chyba, że w ostatniej chwili rywal, który wcześniej szedł mu na kole (Do podjazdu dojechała cała grupa, bo szli na kole Fabiana.), czyli szedt za prowadzacym, 
niespodziewane wyjdzie mu z koła (I niesamowite przyspieszenie Vivianiego, wyjść z koła Niemcowi to wcale nie byto proste.), czyli wychodzi przed prowadzacego na finiszu i idzie na finisz (Jak zwykle na płaskim, cała grupa idzie na finisz.). Inaczej mówiąc, sprowadza się to do tego, żeby odejść komuś (Szuka okazji, na pewno nie ma teraz takiej nogi, żeby odejść wszystkim.) i nie dać się dojść. W przypadku, gdy idq teb $w$ teb (Ciekawy jestem, jak Betancur będzie szedt teb $w$ teb z Purito.), czyli ida koło $w$ koto (Kwiatek szedt koło $w$ koło z Contadorem.), idq na wyniszczenie (A Staruszka, jak wiadomo, to wyścig, gdzie idq na wyniszczenie.) przetrwają tylko najmocniejsi. Gdy prowadzący się zagapi, to rywal wychodzi cichcem na kreskę (Kristoff sam ciagnąt $w$ peletonie $i$ nikt mu z kola na kreskę nie dat rady pójść.), lub idq we dwóch na krechę i dopiero na ostatnich metrach rozstrzyga się, kto pierwszy przejdzie linię mety (Kiedy przechodził linię mety, jechat z prędkościq ponad $60 \mathrm{~km} / \mathrm{h}$.). Natomiast pechowca może przejść kilku rywali, czyli po prostu go wyprzedzić (Stracił dużo, ale przeszedt tę grupkę, jak Cancellara z motorkiem na Roubaix.).

Niektórzy kolarze wolą pójść na metę z długiego finiszu (Adrian Kurek poszedt na metę z dhugiego finiszu, wytrzymat, nie pozwolit się dojść i został Mistrzem Polski., Michat poszedł z długiego na kozaka.), niż przepychać się na ostatnich metrach z rywalami. Tak się może zwłaszcza zdarzyć wtedy, gdy idzie akcja (Decydująca akcja zazwyczaj idzie kilka kilometrów przed meta.) i na czele stawki idzie ucieczka (Ale chtopaki mieli głód sukcesu, że tak liczna i mocna ucieczka poszła na tak plaskim etapie.), w której jakiś kolarz szedt bez zmian (Rafat jechat na rezerwie i dlatego szedt bez zmian.), czyli jechat na świadka i zaoszczędzone $\mathrm{w}$ ten sposób siły mógł wykorzystać podczas wspomnianego długiego finiszu i odejść zmęczonym prowadzeniem grupy rywalom. Zawsze przydaje się umiejętność gwałtownego przyspieszania, czyli odejścia (Mam wrażenie, że z czasem coraz gorzej przyspiesza przy atakach, bo na jakimś Giro kilka lat temu miat catkiem niezłe odejście., Aru pokazat, że odejście ma, choć dziś go przytkało po ataku ACi Cataldo musiat spawać.).

Czasami kolarz z powodu awarii sprzętu lub w wyniku upadku zostaje z tyłu za grupą. Może próbować dojść peleton (Rebellin doszedt peleton na zjeździe.) i w 
tym celu np. iść po samochodach (Dojda po samochodach. Musiałby pójść jakiś straszny gaz, a na to nie wygląda.), tzn. korzystać z osłony samochodów jadących z tyłu peletonu i wyprzedzać innych, czyli przechodzić poszczególne grupki. Szanse wzrastają, gdy zawodnik lekko chodzi po górach, tzn. z łatwością pokonuje wzniesienia, czyli wchodzenie na górę szczególnie mu nie przeszkadza. Po dołączeniu do stawki, gdy ta trzyma się środka szosy, może np. pójść lewa strona (Gdyby Patera nie szedt lewą strona tak szybko, mógłby naprawdę do pierwszej piątki wskoczyć.) i przejść bokiem (Martin chciat ostatni zakręt przejść bokiem), a nawet wyjść na prowadzenie (Spawat wszystko, atakowat, wychodzit na prowadzenie, a w pewnym momencie go zwyczajnie przytkało.). Po jakimś czasie należy zejść z prowadzenia (Brakowało jednak wcześniejszego ataku Michała, np. gdy Martin zszedt z prowadzenia.).

Gdy zawodnicy współpracują i tworzą wachlarz jadąc całą szerokością szosy, aby zmniejszyć opór powietrza, wtedy wchodzi się na wachlarz (Nie dał rady, nie było miejsca, nie zdołat wejść na wachlarz.), schodzi się z wachlarza (Po napędzeniu grupy mógł zejść z wachlarza.) lub przechodzi z wachlarza do wachlarza. Wszyscy jadący na wachlarzu powinni po kolei wchodzić na zmiany, iść po zmianach i schodzić ze zmian (Aby wachlarz się nie rozsypat, trzeba $w$ miarę ptynnie schodzić i wchodzić na zmiany.), choć czasami znajdą się i tacy, którzy będą próbowali iść bez zmian. Cały czas trzeba kontrolować rywali, sprawdzać, czy konkurenci odchodza (Szuka okazji, ale na pewno nie ma teraz takiej nogi, żeby odejść wszystkim.), a najlepiej to robić będąc na przedzie jadących, czyli należy chodzić po czubie (Żeby upilnować głównych rywali musi chodzić po czubie.), szczególnie wtedy, gdy idzie się na wynik indywidualny. Warto w tym miejscu przytoczyć zdanie z niepisanego kodeksu kolarzy stwierdzające, że Lider nie chodzi na premie. Oznacza ono, że liderowi wyścigu nie wypada wygrywać różnych premii lotnych, itp. w trakcie etapu. Gdy zawodnicy nie współpracują, można spróbować iść samemu (Na ostatniej górce należy dołożyć na zjeździe i nie czekać na nikogo, tylko iść samemu), išć solo (Jakby Majka miat siłę, to by poszedt dzisiaj solo.), iść na solo (Aru doszedt grupę na solo.), iść swoim rytmem (Bartek poszedt swoim mocnym rytmem), iść własnym tempem (Lepiej, żeby nie trzymał się Purito, tylko szedł własnym tempem jak się zacznie podjazd.), czyli np. jechać samemu i nie pozwalać innym 
Stefan Wiertlewski: Iść, czyli jechać. Językowy obraz świata w cyklolekcie

wchodzić sobie na koło (Pociagnąt, to znaczy, że ma zapas, sitę, żeby wejść na koło $i$ jechać.). Natomiast, gdy zawodnicy z peletonu przy bocznym wietrze ustawiają się przy krawędzi szosy jeden za drugim tworząc długi wąż, wówczas idzie rant (Jak idzie rant na zawodach ijest wspótpraca, to nie dojdziesz choćbyś byt kozakiem na czas.). Najlepszych stać także w opisywanej sytuacji na odejście od stawki, np. na podjeździe (Na poczq̨tku podjazdu urwat wszystkich $i$ spokojnie odszedł od stawki.). Wówczas niektórzy ida podjazd twardo, że się korby gna (Jedni wola iść podjazd twardo, inni natomiast miękko.).

Niezmiernie ważna jest również technika jazdy. Należy umieć iść $w$ dolnym (Przy czołowym wietrze najlepiej iść $w$ dolnym chwycie.), jak i $w$ górnym chwycie ( $\mathrm{Na}$ finiszu szedł $w$ górnym chwycie. Co za moc.), czyli jechać równie sprawnie z rękoma opartymi na wygiętej dolnej i prostej górnej części kierownicy szosowej. Podstawą jest także pokonywanie zakrętów oraz chodzenie po tuku (Cave szedt po tuku i miat większy dystans do pokonania.), a najlepiej wchodzić w zakręty technicznie (Roelands źle wszedł $w$ zakręt $i$ cały pociąg wytracit przez to prędkość.), choć nie zawsze ma to miejsce (Objechat mnie. Wszedł w zakręt jak bandyta.). Oczywiście należy też umieć wychodzić z zakrętu (Landa trochę za szeroko wyszedł z ostatniego zakrętu i zrobit miejsce Rekinowi). W kolarstwie jest pożądane, aby generalnie potrafić chodzić z wysokim tętnem (Swego czasu chodziłem zawsze z kosmicznie wysokim tętnem i jazda na 210 bpm pod górę nie była czymś niespotykanym.) i chodzić w wysokim rytmie, czyli kręcić z wysoką kadencją (Basso to typowy tempowiec. Chodzi równo w wysokim rytmie.). Niezbędna jest również umiejętność jazdy na kole, czyli tuż za drugim zawodnikiem, choć niektórzy wolą iść na dystans (Nie trzyma się tylnego koła zawodnika jadącego przed nim, tylko idzie na dystans.). Warto także umieć, gdy wymaga tego sytuacja, iść na parze, czyli jechać obok siebie, zwłaszcza na czele stawki. Cały czas trzeba uważać i rozglądać się dookoła, ponieważ jedną z gorszych rzeczy, jakie się mogą przytrafić, to iść na czołówkę, czyli zderzyć się czołowo (Było ciemno, rowery nie miały oświetlenia i poszli na czołówkę.).

Tego samego czasownika iść można użyć także np. przy ocenie właściwości jezdnych opony, jak w zdaniu: Ta opona dobrze idzie na piachu. Tak samo oceni 
się właściwości jezdne konkretnych marek i typów rowerów: Madone idzie po nierównościach z niezwykła starannościa i pewnościa., Przez dziurawe sekcje Geniusz idzie petnym piecem., W porównaniu do górala szosówka idzie do przodu z każdym naciśnięciem pedała. Natomiast rzeczownik derywowany od omawianego czasownika świetnie nadaje się do wyrażenia opinii o pojeździe, np. Rower jest lekki i ma odejście, czyli szybko i z łatwością przyspiesza. Podobnie można powiedzieć, że Rower szedł po asfaltach, brukach i piachach jak wściekty. Gorzej, gdy Koło idzie bokiem, a nie prosto w równych odstępach od ramy.

\section{Zakończenie}

Przedstawione powyżej przykłady w liczbie około 150. pokazują, że czasowniki chodzić i iść oraz ich derywaty uległy neosemantyzacji czy wręcz releksykalizacji i stanowią w cyklolekcie bardzo produktywne narzędzia mówienia o jeżdżeniu, przywołując jednak zarazem wyobrażenia i odniesienia odległe od jazdy na rowerze i przez to ich użycie bywa nieoczywiste. Występują wśród nich przypadki związków wyrazowych o odmiennej składni niż w polszczyźnie ogólnej (odejść komuś, przejść kogoś), porównania (np. iść jak burza/dzik/maszyna/torpeda/wicher) i frazeologizmy (np. idzie gaz/palnik/petarda/rura, idzie zaciąg, idzie gaz i wyciągara, iść na zapieku, iść $w$ odjazd). W zdecydowanej większości przywołanych przypadków nie da się jednak w obrębie omawianej odmiany czasowników iść - chodzić zastąpić czasownikiem jechać. $\mathrm{Z}$ powodu powszechności ich występowania i łatwości tworzenia charakterystycznych połączeń wyrazowych ta ich specyficzność nie musi być dostrzegana w codziennej komunikacji środowiska kolarskiego, gdyż stały się one niejako przezroczyste. Oczywiście o jeździe na rowerze można też mówić m.in. za pomocą nie omawianego tutaj czasownika jechać, choć w cyklolekcie znacznie częściej, jak się wydaje, występują odwołania do wyobrażeń związanych z chodzeniem.

Jeśli na przeanalizowaną powyżej sytuację spojrzeć przez pryzmat metafory pojęciowej - o jej wykorzystaniu w rekonstruowaniu językowego obrazu świata pisałem w innych miejscach (por. np. Wiertlewski 2008) - wówczas przybierze ona następującą formę:

\section{JAZDA NA ROWERZE TO CHODZENIE}


Warto przy tym zauważyć, że w takim przypadku dwie powiązane domeny pojęciowe są bliskie doświadczeniu fizycznemu, co nie jest zbyt częste (Kövecses 2011:178), gdyż zazwyczaj jedna z nich (domena docelowa) ma charakter bardziej abstrakcyjny.

Jak pokazałem, sposób mówienia o jeździe na rowerze ze względu na dobór słów i przywoływane przez nie wyobrażenia bywa zaskakujący, ale jednocześnie wymagający od członków rozpatrywanego środowiska sporej wiedzy na temat specyficznych znaczeń omówionych jednostek i dodatkowo sporego wyczucia językowego. Mamy tu mianowicie odwołania do wyobrażeń normalnie nie kojarzonych z działalnością dotyczącą roweru, ale przez taki właśnie ich wybór jej wizerunek w specyficzny sposób współkształtujących. Należy się tego nauczyć, choćby w pewnym ograniczonym stopniu, zwłaszcza, jeśli komuś zależy na poczuciu przynależności środowiskowej. Rzeczywistość, także kolarska, jest w pewien sposób bezgłośna czy wręcz niema. Dopiero dobór słów nazywających elementy tej rzeczywistości i sposób ich użycia tworzy jej językowy obraz - w przypadku niniejszego tekstu są to leksemy używane w polszczyźnie ogólnej, które w wyniku neosemantyzacji wyrażają nowe znaczenia dotyczące realiów środowiska kolarskiego i poprzez ich nazwanie jakoś wyodrębnione. Jednocześnie jednak, omówione słowa nie tracąc swych dotychczasowych odniesień, przywołują kolejne wyobrażenia oraz pozwalają wyrazić świat wartości preferowanych w analizowanym środowisku. 


\section{Bibliografia}

Bartmiński J. 2006. Językowe podstawy obrazu świata, Lublin: Wydawnictwo Uniwersytetu Marii Curie-Skłodowskiej.

Grabias S. 1997. Język w zachowaniach spolecznych, Lublin: Wydawnictwo Uniwersytetu Marii Curie-Sklodowskiej.

Handke K. 2008. Socjologia języka. Warszawa: Wydawnictwo Naukowe PWN.

Kövecses Z. 2011.Język, umyst, kultura, Kraków: Universitas.

Piekot, T. 2008. Język w grupie społecznej. Wprowadzenie do analizy socjolektu. Wałbrzych: Wydawnictwo Państwowej Wyższej Szkoły Zawodowej.

Wiertlewski S. 2008. „Metafora pojęciowa jako narzędzie rekonstruowania językowego obrazu świata w socjolekcie rowerowym”, Język, Komunikacja, Informacja 3, str. 79 -89 .

Wiertlewski S. 2016. „Rower i jazda rowerem z perspektywy metafory konceptualnej”, w: A. Czapla, M. Koper (red.), Język i sport, Lublin: Fotopia, str. 133 - 148. 